\title{
EVALUATION OF THREE SURFACE FRICTION TECHNIQUES FOR THE REMOVAL OF ORGANIC MATTER ${ }^{1}$
}

\author{
Marcelo Alessandro Rigotti², Adriano Menis Ferreira ${ }^{3}$, Mara Corrêa Lelles Nogueira ${ }^{4}$, Margarete Teresa \\ Gottardo de Almeida ${ }^{5}$ Odanir Garcia Guerra ${ }^{6}$, Denise de Andrade
}

\footnotetext{
${ }^{1}$ This work is part of the Doctoral Project - Evaluation of cleaning protocols/disinfecting hospital surfaces, under development by the Programa de Pós-Graduação em Ciências da Saúde da Faculdade de Medicina de São José do Rio Preto (FAMERP)

${ }^{2}$ Doctoral student at the Programa de Pós-graduação em Ciências da Saúde, FAMERP. Assistant Professor at the Nursing and Medical Course of the Universidade Federal de Mato Grosso do Sul (UFMS). Três Lagoas, Mato Grosso do Sul, Brazil. E-mail: marcelosaude@hotmail.com

${ }^{3}$ Ph.D. in Nursing. Professor at Programa de Pós-Graduação em Saúde e Desenvolvimento na Região Centro-Oeste,. Três Lagoas, Mato Grosso do Sul, Brazil. E-mail: a.amr@ig.com.br

${ }^{4}$ Ph.D. in Biological Sciences. Professor at Programa de Pós-graduação em Ciências da Saúde, FAMERP. São José do Rio Preto, São Paulo, Brazil. E-mail: ml.nogueira@famerp.br

${ }^{5}$ Ph.D. in Health Sciences. Professor at the Programa de Pós-graduação em Ciências da Saúde, FAMERP. São José do Rio Preto, São Paulo, Brazil. E-mail: margarete@famerp.br

${ }^{6}$ Ph.D. in Biological Sciences. Professor at the UFMS. Três Lagoas, Mato Grosso do Sul, Brazil. E-mail: ogguerra@yahoo.com

7 Ph.D. in Nursing. Associate Professor at Programa de Pós-graduação em Enfermagem Fundamental, Escola de Enfermagem de Ribeirão Preto, Universidade de São Paulo. Ribeirão Preto, São Paulo, Brazil. E-mail: dandrade@eerp.usp.br
}

\begin{abstract}
The objective of this study was to assess the effectiveness of three surface friction techniques for the removal of organic material. A quantitative, descriptive and exploratory study was developed to evaluate the presence or not of organic material before and after the cleaning and disinfection process of surfaces of bedside tables of patients hospitalized at an Intensive Care Unit. Three friction techniques were executed in the one-way, two-way and centrifugal sense, individually, three times on each table, during alternate weeks. For each patient unit and friction technique, a single table and three sides of cloth were used, moistened with 70\% (w/v) alcohol. The organic matter was detected through the presence of adenosine triphosphate by bioluminescence, using $3 \mathrm{M}^{\mathrm{TM}} \mathrm{Clean}$-Trace ${ }^{\mathrm{TM}} \mathrm{ATP}$ Systems. For each technique, 13 samples were collected before and 13 after the cleaning/disinfection process, totaling 78 samples of adenosine triphosphate by bioluminescence. No statistically significant difference was found among the removal techniques of organic matter. This study demonstrated that none of the three surface friction methods was better than the other to remove organic matter. Nevertheless, further research is needed in which other cleaning/disinfection indicators and surfaces are considered.
\end{abstract}

DESCRIPTORS: Housekeeping, hospital. Comparative study. Disinfection. Environmental contamination control. 2-Propanol. Adenosine triphosphate.

\section{AVALIAÇÃO DE TRÊS TÉCNICAS DE FRICÇÃO DE SUPERFÍCIE PARA REMOÇÃO DE MATÉRIA ORGÂNICA}

\begin{abstract}
RESUMO: Objetivou-se avaliar a eficiência de três técnicas de fricção de superfície para remoção de matéria orgânica. Trata-se de um estudo quantitativo, descritivo e exploratório, realizado antes e após o processo de limpeza/desinfecção das mesas de cabeceiras da unidade de pacientes. Três técnicas de friç̧ão em sentido unidirecional, bidirecional e centrífuga, realizadas individualmente para cada mesa, foram executadas. Para cada unidade de paciente e técnica de fricção, uma única mesa e pano umedecido com álcool a $70 \%(\mathrm{p} / \mathrm{v})$ foi empregado. A matéria orgânica foi detectada pela presença de trifosfato de adenosina por bioluminescência utilizando o sistema 3M $\mathrm{M}^{\mathrm{TM}}$ Clean-Trace ${ }^{\mathrm{TM}}$ ATP Systems. Para cada técnica, 13 amostras foram coletadas antes, e 13, após o processo de limpeza/desinfecção, totalizando 78 colheitas. Não se constatou diferença entre as técnicas na remoção de matéria orgânica. Este estudo demonstrou que as três técnicas de fricção de superfície são equivalentes. No entanto, estudos adicionais considerando outros indicadores e superfícies são necessários.
\end{abstract}

DESCRITORES: Serviço hospitalar de limpeza. Estudo comparativo. Desinfecção. Controle da contaminação ambiental. 2-Propanol. Trifosfato de adenosina. 


\title{
$-1062-$ \\ Rigotti MA, Ferreira AM, Nogueira MCL, Almeida MTG, Guerra OG, Andrade D \\ EVALUACIÓN DE TRES TÉCNICAS DE FRICCIÓN DE SUPERFICIE PARA REMOCIÓN DE MATERIA ORGÁNICA
}

\begin{abstract}
RESUMEN: Se objetivó evaluar la eficacia de tres técnicas de fricción de superficie para remoción de materia orgánica. Se trata de un estudio cuantitativo, descriptivo y exploratorio sobre evaluación de la presencia o no de materia orgánica antes y después del proceso de limpieza/desinfección de la superficie de mesillas de noche de pacientes internados en una Unidad de Terapia Intensiva. Tres técnicas de fricción en sentido unidireccional, bidireccional y centrífuga fueron ejecutadas individualmente tres veces para cada mesilla, en semanas alternadas. Para cada unidad de paciente y técnica de fricción, una única mesilla y paño, utilizando 3 faces y humedecido con alcohol a $70 \%(\mathrm{p} / \mathrm{v})$ fueron utilizados. La materia orgánica fue detectada por la presencia de trifosfato de adenosina por bioluminescencia, utilizando el sistema $3 \mathrm{M}^{\mathrm{TM}}$ Clean-Trace ${ }^{\mathrm{TM}}$ ATP Systems. Para cada técnica, 13 muestras fueron recolectadas antes y 13 después del proceso de limpieza/desinfección, totalizando 78 recolectas de trifosfato de adenosina por bioluminescencia. No fueron constatadas diferencias estadísticamente significativas entre las técnicas en la remoción de materia orgánica. Este estudio demostró que ningún de los tres métodos de fricción de superficie fue mejor que los otros en la remoción de materia orgánica. Sin embargo, estudios adicionales son necesarios, considerando otros indicadores de limpieza/desinfección y superficies.
\end{abstract}

DESCRIPTORES: Servicio de limpieza en hospital. Estudio comparativo. Desinfección. Control de la contaminación ambiental. 2-Propanol. Adenosina trifosfato.

\section{INTRODUCTION}

It is a fact that the environmental contamination involving important microorganisms (meticillin resistant Staphylococcus aureus MRSA, vancomycin resistant Enterococus - VRE, Acinetobacter, norovirus, and Clostridium difficile) represents risks of microbial transmission between patients and professionals. In that sense, it is proven that cleaning and/or disinfection of the environment can reduce environmental surface contamination, contributing to reduce healthcare-associated infections. ${ }^{1-2}$ On the other hand, many researchers have demonstrated that workers in charge of cleaning/disinfection of commonly touched environmental surfaces do not clean them adequately. Considering the understanding of the importance of the role played by the environment in the transmission of microorganisms, the Centers for Disease Control and Prevention (CDC) and the Healthcare Infection Control Practices Advisory Committee (HISPAC) recommend particular attention towards cleaning and disinfection of commonly touched surfaces that are close to patients, and that healthcare facilities should ensure adequate compliance by professionals to these procedures. ${ }^{3-4}$ What is contradictory, though, is that they do not indicate the way to perform the friction technique on these surfaces.

Environmental surfaces consist of an important reservoir of microorganisms, and therefore require efficient cleaning and disinfection methods, even in face of validation difficulties. ${ }^{3-9}$

Among scholars, there is consensus regarding the benefits of surface cleaning and disinfec- tion, even in face of the scarcity of minimum quality standard indicators. This means environments and surfaces are nearly exclusively evaluated via visual inspection, meeting aesthetic standards without considering the results of measurement of organic and microbial materials in terms of infection risk for patients. ${ }^{10-11}$

In this sense, the efficiency of cleaning and disinfection processes, referred to as cleaning/ disinfection procedure in this study, must be investigated as a scientific process with measurable results. Consequently, the procedure must include methods to monitor its efficiency/effectiveness. For that matter, the visual evaluation of surfaces, the determination of the total aerobic colony count (ACC) and/ or culture of an indicator microorganism, in addition to the detection of organic material through the presence of adenosine triphosphate (ATP) by bioluminescence are techniques that have been available for more than 30 years. ${ }^{6,12-14}$ Regarding the detection of adenosine triphosphate by the bioluminescence technique, specifically, it is considered to be an easy method to apply that can be used for evaluating cleaning/disinfection of environmental surfaces, since it detects organic material through ATP presence, which can be substratum for microorganisms. ${ }^{12}$

However, in order to have an adequately clean environment, it is not clear whether changes must be made to the cleaning/disinfection products, procedures, friction technique, or professionals' performance. $^{2}$

Particularly, the type of movement performed to rub a surface in order to clean it is an 
unresolved issue, since we have not identified in literature any references to the recommended movements to be made in surface friction. Thus, the efficiency of unidirectional, bidirectional and centrifugal friction lack scientific research needed to fill in this gap in knowledge.

It is noteworthy that, according to international agencies, no recommendation is made on the friction technique to clean/disinfect surfaces, nor on the amount of friction and amount of detergent and/ or disinfectant that must be used. ${ }^{3-4}$

A study has shown, though, that professionals who performed the cleaning/disinfection of one single surface, rubbing it up to 10 times in a total of 10 seconds, and using the same cloth in up to five different surfaces before disposing of it, did not take into account the friction technique. ${ }^{15}$

Therefore, in face of the questions that still need answers concerning the more adequate friction techniques for fixed surfaces to guarantee their cleaning/disinfection, we ask whether the ways to perform the friction of a surface will lead to different or similar results in terms of how much organic material is detected by the presence of adenosine triphosphate by bioluminescence. Consequently, the object of this study was to compare and contrast the efficiency of three surface friction techniques in reducing organic material.

\section{METHOD}

A quantitative, descriptive and exploratory study was conducted at an Intensive Care Unit (ICU) with 24 mixed-gender beds, at a large teaching hospital. The occupation rate of the beds during the sample collection was $100 \%$. This study was conducted for three weeks.

\section{Selected surface}

Each patient unit had two bedside tables. However, only 13 tables were selected for the experiments before and after the cleaning/disinfection process. Thus, a table of each patient's unit was listed for the evaluation. We point out that this was due to the scarcity of available resources for the use of swabs to detect organic material. The Formica ${ }^{\circledR}$ tables measured $87 \times 36 \mathrm{~cm}$ (Figure 1).

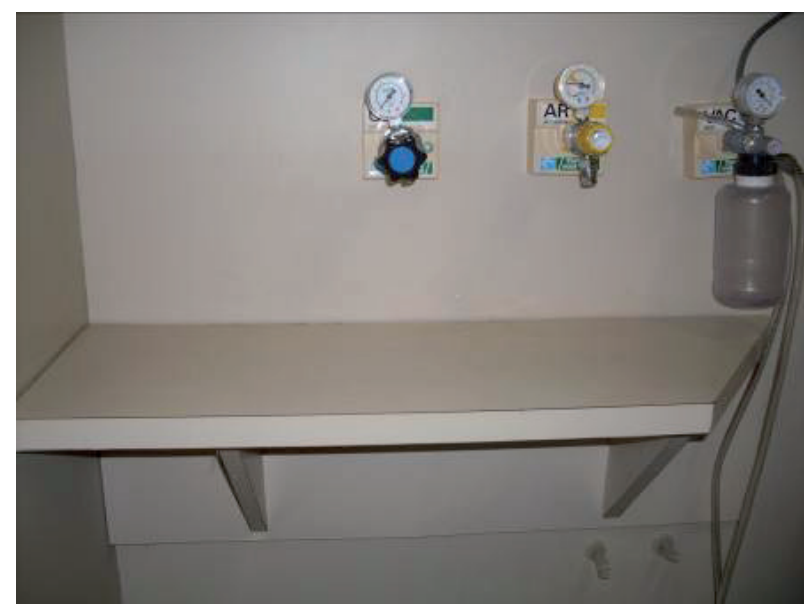

Figure 1 - Image of bedside table used in the study

\section{Friction techniques and materials}

Three friction techniques were compared: A) unidirectional; B) bidirectional and C) centrifugal (Figure 2).

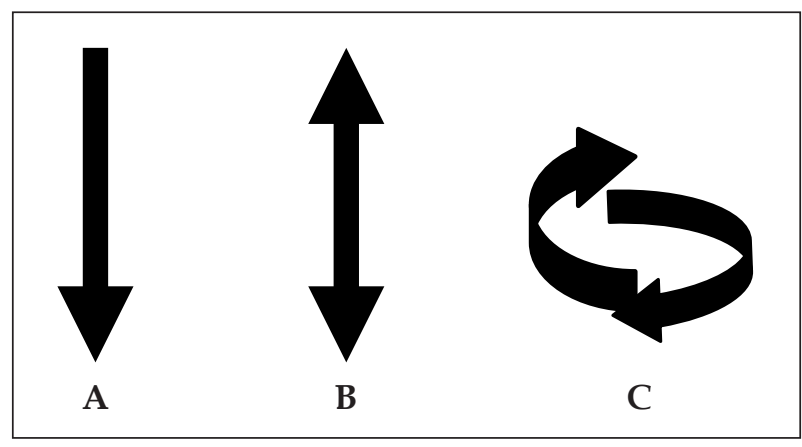

Figure 2 - Schematic representation of friction technique types

We must clarify that in the service evaluated, the disinfection routine of bedside tables was supposed to be done at the beginning of each shift. Therefore, researchers came to the ICU in the morning, before the nursing team carried out the procedure. This means the surfaces were probably left without cleaning/disinfection for nearly 12 hours. During the period of this study (collectiondisinfection-collection), no professional used the table to perform any activities, in order not to add any more organic material to whatever was left after the previous cleaning/disinfection procedure. 
To ensure that all tables were granted equal possibility to be included in the study and applied the three friction techniques, we carried out a drawing on a randomization program (http:// www.randomizer.org). Consequently, the rotation of the 48 tables ensured that each technique was carried out in the same environment during the period of this study. On a particular day of the week, only one type of experiment (friction technique) was performed on each one of the 13 selected tables and a one-week interval among them was made.

In this study, we used a new microfiber cloth, measuring $21 \times 19.5 \mathrm{~cm}$, made up of $80 \%$ viscose, $15 \%$ polypropylene, and $5 \%$ polyester. A single cloth was used on each bedside table. ${ }^{16}$

We used nonprobability convenience sampling. However, to ensure the reproducibility of the friction techniques, we based this research on a previous study; ${ }^{16}$ therefore, each experiment was repeated 13 times before and 13 after the cleaning/disinfection, applying friction three times, using a new cloth for each bedside table. We highlight that a new side of the cloth was used for each of the three frictions per technique (unidirectional, bidirectional and centrifugal) and table. ${ }^{16}$ The degree of pressure in the friction was not studied.

Aiming at replicating the practice in service, we used $70 \%$ hydrated ethyl alcohol (w/v) of the Rioquímica ${ }^{\circledR}$ brand, registered in the Brazilian Ministry of Health, under n. 3,1329,0010,004-5 as a hospital disinfectant for fixed surfaces, providing average or intermediate level disinfection. The previous cleaning of surfaces with water and soap/detergent was not performed, since it was not part of the service routine. The disinfectant was sprayed 20 times on each cloth, until it was completely moistened. Two researchers cleaned/ disinfected the studied surfaces and wore a pair of sterile gloves for each friction technique on each table. The overall mean time of friction, regardless of the technique used, was 38 seconds, \pm 5.3 .

\section{Tests used}

The collection was made before and after the cleaning/disinfection of surfaces. After finishing the procedure, we waited 10 minutes to let the surface dry.

The test of adenosine triphosphate by bioluminescence $\left(3 \mathrm{M}^{\mathrm{TM}}\right.$ Clean-Trace ${ }^{\mathrm{TM}}$ ATP System) was used to measure the capacity of techniques to remove organic matter and demonstrate which one of the friction techniques would be more efficient in removing organic material with ATP. This technology detects ATP from organic residues (human secretions, excretion and blood; foods and other types of organic material), including viable and non-viable microbial count (probably recently dead microorganisms). Bioluminescence uses light to measure organic material and this measurement can be used as a hygiene indicator. Light is emitted in direct ratio to the amount of ATP and is measured in relative light units (RLU). The higher the reading, the higher the ATP level and consequently, the level of organic load. Therefore, ATP monitoring provides a simple and quantitative method to demonstrate cleaning effectiveness/ efficiency. ${ }^{12}$

To collect ATP from microorganisms and existing organic material on the tables' surface, one cotton swab that is part of the Clean Trace ${ }^{\mathrm{TM}}$ kit was rubbed on the entire surface area, forming a $30^{\circ}$ angle, 20 times in zigzag diagonal directions, thus minimizing the variability in the measurement method. After that, the swab was inserted in a cuvette and agitated manually for five seconds, then immediately inserted in a luminometer that performed the reading in 10 seconds.

Although this has not been the research objective, a surface was considered "clean" (approval rate) when the reading was less than 500 RLU. ${ }^{13}$ However, prospective studies have not demonstrated that this value is associated with reducing the transmission of pathogenic agents associated with healthcare. ${ }^{12}$

The collected data were entered into an Excel spreadsheet for analysis, and into the program Statistical Package for the Social Sciences, version 15.0. Mean, median and variation were used. For each technique, ATP means were compared by Friedman nonparametric test for dependent groups, which enabled to analyze the results of an experimental randomized block design, when the prerequisites that are needed to analyze parametric variance, namely those that refer to normality and homoscedasticity (homogeneity of variance), are not fulfilled, or when the sample is restricted. Thus, we sought to find statistical difference among the friction techniques before and after the cleaning/disinfection process. These hypotheses were established: $\mathrm{H}_{0}$ : the three surface friction techniques are not equivalent for removing 
organic material and $\mathrm{H}_{1}$ : the three surface friction techniques are equivalent for removing organic material. The significance level adopted for the statistic test was $5 \%(\mathrm{p}<0.05)$.

\section{RESULTS}

A total of 26 ATP tests were performed (13 before and 13 after cleaning/disinfection) for each friction technique. Therefore, of the 78 collections of ATP by bioluminescence obtained in this study, we concluded that the failure rates of cleaning before the unidirectional, bidirectional and centrifugal techniques were $100 \%, 92.3 \%$ and $100 \%$, respectively. Regarding the approval rates for the same techniques after the cleaning procedure, they were $61.5 \%, 76.9 \%$ and $69.2 \%$, respectively. This means $38.5 \%, 23.1 \%$ and $30.8 \%$ of the surfaces did not reach the adopted cleanliness standards (ATP value below 500 RLU) after the cleaning/ disinfection process with the techniques in the three different directions.

There was no significant statistic difference $(p=0.689)$ among the techniques by the Friedman test (for the difference between before and later); consequently, we rejected the null hypothesis $\left(\mathrm{H}_{0}\right)$, even though the descriptive values (means and medians) were different (Tables 1 and 2).

Table 1 - Mean, median and variation values of organic material detected by ATP/RLU, before and after surface cleaning/disinfection, with three techniques. São José do Rio Preto, São Paulo, Brazil, 2013

\begin{tabular}{|c|c|c|c|c|}
\hline \multirow[b]{2}{*}{ Friction techniques } & \multirow[b]{2}{*}{ ATP Samples } & \multicolumn{3}{|c|}{ ATP*-RLU† } \\
\hline & & $\begin{array}{c}\text { Mean } \\
\text { (minimum-maximum) }\end{array}$ & $\begin{array}{c}\text { Median } \\
\text { (minimum-maximum) }\end{array}$ & Variation \\
\hline \multirow{2}{*}{ Unidirectional } & Before & $\begin{array}{c}2223 \\
(540-4006)\end{array}$ & $\begin{array}{c}1229 \\
(570-11508)\end{array}$ & 8707 \\
\hline & After & $\begin{array}{c}496 \\
(269-723)\end{array}$ & $\begin{array}{c}427 \\
(69-1329)\end{array}$ & 1260 \\
\hline \multirow{2}{*}{ Bidirectional } & Before & $\begin{array}{c}4474 \\
(767-5716)\end{array}$ & $\begin{array}{c}1119 \\
(133-38187)\end{array}$ & 38054 \\
\hline & After & $\begin{array}{c}342 \\
(114-569)\end{array}$ & $\begin{array}{c}164 \\
(59-1211)\end{array}$ & 1152 \\
\hline \multirow{2}{*}{ Centrifugal } & Before & $\begin{array}{c}4265 \\
(520-8550)\end{array}$ & $\begin{array}{c}1210 \\
(535-24842)\end{array}$ & 24307 \\
\hline & After & $\begin{array}{c}572 \\
(9-1135)\end{array}$ & $\begin{array}{c}327 \\
(74-3566)\end{array}$ & 3492 \\
\hline
\end{tabular}

${ }^{*} \mathrm{ATP}=$ adenosine triphosphate; $\uparrow \mathrm{RLU}=$ relative light units.

Table 2 - Values of difference among means, medians, variations and standard deviation of organic material detected by ATP/RLU, before and after surface cleaning/disinfection, with three techniques. São José do Rio Preto, São Paulo, Brazil, 2013

\begin{tabular}{ccccc}
\hline \multirow{2}{*}{ Friction techniques } & \multicolumn{4}{c}{ ATP*/RLU† BEFORE-AFTER } \\
\cline { 2 - 5 } & Mean & Median & Variation & Standard deviation \\
\hline Unidirectional & 1726 & 920 & 10776 & 2868 \\
Bidirectional & 4132 & 842 & 36902 & 10076 \\
Centrifugal & 3692 & 1097 & 21223 & 6350 \\
\hline
\end{tabular}

*ATP, adenosine triphosphate; † RLU, relative light units

Mean RLU and confidence intervals (CI) for the three techniques were the following: the unidirectional technique had a mean of 1,726 RLU (95\% CI, -6,4-3,460); the bidirectional, 4,132 RLU (95\% CI, -1,957-10,221); and the centrifugal, a mean of 3,692 RLU (95\% CI, -144-7,529). There was no statistically significant difference in the amount of ATP for each one of the three techniques after cleaning/disinfection.

\section{DISCUSSION}

To evaluate the different ways to rub surfaces, this study's objective was to measure the 
efficiency of three friction techniques applied to Formica ${ }^{\circledR}$ surfaces by measuring residual organic matter, before and after cleaning/disinfection.

The results of this research demonstrated that there is no statistically significant difference among unidirectional, bidirectional, and centrifugal friction techniques for reducing organic material measured by the presence of ATP.

In face of these results, it seems that the cleaning/disinfection efficiency is more based on its dirtiness removal capacity by means of applying enough friction than on the mere rubbing of moistened cloth in predetermined directions. However we must consider the type of cloth used, its folding during friction, the amount, concentration and time of contact with the surface, as well as the presence of organic material, the type and level of microbial contamination and the presence of biofilm.

Governmental agencies and professional associations, amongst others, describe cleaning/ disinfection specifications for wards, outpatient facilities, operating rooms, and areas that are not occupied by patients, in addition to pointing out the need for cleaning/disinfection monitoring methods. Some countries are producing national standards for environment cleaning/disinfection..$^{3-4,17}$ These initiatives are necessary and create a valuable precedent; at times, though, they are not based on scientific foundations that justify their content. This is a concerning fact in the Brazilian reality, since we have not found research or scientifically based recommendations for the best way to clean/disinfect hospital surfaces, nor have we found information about products, techniques or materials for the adequate removal of organic material and microorganisms, particularly when there is no possibility to perform previous cleaning and rinsing with good quality running water.

Just recently did Brazil's National Health Surveillance Agency (ANVISA, as per its acronym in Portuguese) publish a manual that deals with surface cleaning and disinfection. ${ }^{17}$ This fact represents great improvement for this area. However, the manual fails to comprehensively describe more modern methods to evaluate the cleaning/disinfection of these surfaces and this may overstress visual inspection as the easiest, most feasible method.

We highlight that cleaning has two main functions. The first is non microbiological, aiming to improve or restore the environment's appearance, to keep its function and to prevent deterioration. The second is microbiological and is intended to reduce the number of microorganisms and any substances that work as a substratum for their growth, or interfere with the subsequent disinfection or sterilization processes. ${ }^{18}$ Therefore, the term cleaning can be interpreted in different ways, ${ }^{19}$ which led us to use the term cleaning/disinfection when the sanitizing products used were formulated with a detergent (surfactant) and a disinfectant, or the alcoholic solution that, in a recent study ${ }_{,}^{20}$ was proven to have both antimicrobial and cleaning properties in terms of visual inspection, something that was not previously known.

We highlight that the classic, consensual recommendation of safe methods for disinfecting surfaces consists of previously cleaning the place, followed by disinfecting with a microbicide agent. ${ }^{3,17}$ Nevertheless, in this research, the cleaning with water and soap/detergent stage was not performed because it is not a common practice at the researched unit. Actually, in the practice of care, the direct application of alcohol on surfaces without previous cleaning is followed relatively often. ${ }^{20}$

A Brazilian experimental, randomized and simple blind laboratory study evaluated the disinfecting effectiveness of alcohol $70 \%$ (w/v) under friction on surfaces (in circular movements) for $30^{\prime \prime}$, without previous cleaning, as a concurrent disinfection procedure. ${ }^{20}$ The samples consisted of glazed surfaces, intentionally contaminated by microorganisms Serratia marcescens ATCC 14756 $10^{6}$ colony-forming units/mL $(\mathrm{CFU} / \mathrm{mL})$, added by $10 \%$ human saliva and submitted to disinfection procedure with no previous cleaning. Results were compared with those of disinfection preceded by cleaning with water and detergent, under friction (using circular movements), followed by rinsing and disinfection by application of $70 \%$ alcohol, for $30^{\prime \prime}$. There was a reduction of six logarithms of the initial microbial population, equally in the groups with and without previous cleaning $(p=0.440)$ and residual microbial count $\leq 10^{2} \mathrm{CFU}$, showing no difference between the disinfecting effectiveness of $70 \%$ alcohol under friction, when applied with and without previous cleaning on surfaces intentionally contaminated. Another interesting finding in this study was the visual inspection of the properties of alcohol as a cleaning agent. ${ }^{20}$ Although the findings of this study are relevant, we must take into account that glazed surfaces and friction for $30^{\prime \prime}$ do not seem to be a reality in the cleaning/disinfection practices when it comes to 
surfaces at healthcare facilities. Additionally, the type of cloth and the amount of alcohol used in each experiment were not described.

Although some products on the market clean and disinfect contaminated surfaces when applied to them on a single stage, using a technique known as spray-wipe, $70 \%$ alcohol is the most widely available and used product in the everyday reality of Brazilian healthcare facilities, mainly due to its lower cost when compared with these new products. ${ }^{20}$

It is worth pointing out that important components of an efficient surface cleaning/ disinfection procedure must involve monitoring the effectiveness of the methods used. One way to evaluate the cleaning/disinfection process is ATP measurement. ATP is present in all viable procaryotic microorganisms and eucaryotic human cells. Therefore, the RLU detected before and after cleaning/disinfection, regardless of the friction technique, may represent the microbial density or residual secretions that contain cellular ATP of patients and professionals. ${ }^{21}$ Normally, it is probable that about $33 \%$ of the ATP from surfaces touched by hands have microbial origin. ${ }^{22}$ On the other hand, studies show that the detection limit (i.e., the lowest microorganism level that would generate 1 RLU, using Clean-Trace ATP test kit; $3 \mathrm{M}^{\mathrm{TM}}$ Inc.) for viable bacteria was $\sim 10^{2} \mathrm{CFU} / \mathrm{ml}$ and $\sim 10^{3} \mathrm{CFU} / \mathrm{ml}$ of gram-negative and gram-positive bacteria, respectively. Thus, the relation between RLU and colony-forming units is not linear. ${ }^{22-23}$

The comparison of the three friction techniques adopted in this research, using ATP detection as an evaluation parameter, aimed to establish which of the techniques would be capable of removing dirtiness from surfaces in order to measure and reproduce it. We found that the cleaning/disinfection was efficient with no statistically significant difference among the friction techniques in terms of organic material reduction on surfaces that are commonly found in clinical environments. This confirms the recommendation by the National Agency, which recommends the application of $70 \%$ alcohol ${ }^{17}$ unidirectionally for three consecutive times; nevertheless, it does not describe other variables or support this recommendation with scientific evidence.

Various studies state that ATP monitoring is an important tool for auditing cleaning. ${ }^{11-12,21}$ In this sense, as we have previously described, ATP analysis measures microbiological and non-microbiological ATP sources, which can be removed through an effective cleaning/disinfection protocol that must take the friction technique into account, amongst others variables. The test can be used to supply instant data feedback on the cleaning of surfaces, working as an instrument to demonstrate the flaws in the cleaning/disinfection routines or techniques, assess protocols and train the professionals who perform these activities. ${ }^{11,21}$

An estimated $20 \%$ to $40 \%$ of hospital infections' etiologies are associated with cross infection by the hands of healthcare professionals who are contaminated through direct contact with patients, or indirectly touching contaminated surfaces. ${ }^{24} \mathrm{It}$ is not surprising that, due to the frequent interaction with hospital surfaces and patients, healthcare professionals and visitors may transfer secretions, oils, skin cells and microorganisms to these surfaces. Over time, a film is formed by inorganic salts, organic material, and microorganisms that accumulate through this physical contact and presumably facilitate the growth and transmission of viable microorganisms through the environment. ${ }^{25}$ Thus, the ways the friction of surfaces is performed can be considered an important variable to be studied. This study found no differences among them.

Consequently, routine surface disinfection procedures at healthcare facilities are being listed as potentially inadequate, perpetuating surfaces as microbial reservoirs, even after cleaning/disinfection. ${ }^{9,14}$ In some hospitals, visual inspection of surface cleaning has been adopted as the only criterion to evaluate this process. However, surfaces that fit the visual cleaning criterion often remain contaminated by microorganisms or other organic materials. ${ }^{8,11,13,21}$ It is odd that these same studies do not focus on, describe or compare friction techniques with detergents and/or disinfectants on the surfaces evaluated.

The cleaning/disinfection process is performed with the aim to remove microorganisms from a surface. Therefore, this process is also expected to be capable of reducing organic substances to low levels. ${ }^{21}$ Consequently, in this study we can state that the cleaning of surfaces with the three friction techniques, using $70 \%$ alcohol, reduced $61.5 \%$ to $76.9 \%$ of organic matter to acceptable levels (<500 RLU), depending on the used technique, though an RLU cut-off that can be associated with an increase or reduction in healthcare-associated infections has not yet been validated.

With the use of the three friction techniques, a complete surface cleaning was not achieved, but 
this can be explained by the high ATP rates found before the procedures, which varied between 133 and 38,187 RLU. In addition, the cleaning was performed by rubbing the cloth only three times in each direction, even though it was folded in each cycle.

It is noteworthy that we found only one study comparing two disinfection techniques for hospital mattresses using $70 \%$ alcohol, ${ }^{26}$ which sought to test its effectiveness in reducing microorganisms. Of the six beds analyzed in technique 01 (unidirectional cleaning, from the cleaner towards the most contaminated area), four had contamination before the cleaning, which was reduced in two $(50 \%)$ of the mattresses studied. On the other hand, in technique 02 (circular movements, regardless of the contamination degree), microbes were reduced in all the six $(100 \%)$ mattresses studied.

The study found evidence of the presence of Staphylococcus aureus in the studied periods, ${ }^{26}$ i.e., before and after disinfection. Although technique 02 presented greater reduction in microbial count, it is necessary to conduct new studies with a higher number of mattresses, also including products and improvement of new techniques. It is important to emphasize that, different from our study, the aforementioned study found better results with the circular movement technique, although we used another indicator (ATP) to measure the cleaning/disinfection level. Additionally, it dealt with flexible surfaces (mattresses) rather than the hard ones researched in our study. This issue is still an area that needs greater investment in terms of research, since disinfectants are tested on hard surfaces without the application of friction.

We highlight that, in the previous study, ${ }^{26}$ the authors mention that they performed the cleaning "from the cleaner towards the most contaminated area." This practice, however, has been perpetuating in nursing for decades and it is obvious that, by the naked eye, it is not possible to determine which area is more or less contaminated on a surface that seems to be uniformly "clean."

Recent research tested the efficiency of $70 \%$ alcohol in cleaning/disinfection of telephone devices, ${ }^{27}$ electrocardiogram and duty roster. The cleaning/disinfection procedure consisted of direct application of the product, without preceding water and soap cleaning, using a standard cleaning cloth soaked into the solution, one for each type of equipment, in a single direction, repeating several times until cleaning the apparent dirtiness. An average of three consecutive times minimum was noticed and there was no interval for drying between movements. In this study, the use of the alcoholic solution was efficient and eliminated the bacteria immediately after its use, even without previous water and soap cleaning before the application.

It is undisputed that the prevention of crossed contamination by healthcare-assiociated infection between patients and healthcare professionals is an imperative issue for the patient's safe care, although it presents a great challenge. Nonetheless, the possible participation of environmental factors, such as surfaces and equipment amongst other objects and instruments used by healthcare professionals calls the attention of researchers, society, and infection control agencies and associations. ${ }^{4,28}$ In fact, we can no longer ignore them in the infection transmission chain.

Our study has some limitations. Despite the existence of a Brazilian recommendation to clean surfaces by applying detergent before the alcoholic disinfectant, the detergent was not used because it does not consist of a service routine in our field of study. The amount of organic material was not standardized and was therefore variable. On the other hand, it represents the clinical reality. Each table was rubbed three times for each method by two trained researchers, so the results would accurately reflect the efficiency of the friction techniques and of the disinfectant used, since they could be adversely influenced by inadequate cleaning/disinfection practices performed by the professionals of the studied unit. ${ }^{12,16}$

We also point out that the disinfection was performed on a single type of surface (Formica $\left.{ }^{\circledR}\right)$. Due to scarce financial resources, we could not perform the quantification of total aerobic colonies on the surfaces, which could have contributed to a better understanding of the cleaning/disinfection process with the tested techniques. Different types of surfaces, cloths and disinfectant could have performed differently. On the other hand, this study provides advancements in terms of nursing knowledge, since until this moment we have not found any previous research conducted in clinical environments addressing the subject applied to hard surfaces commonly found in healthcare facilities.

\section{CONCLUSION}

This study provides evidence that the three surface friction techniques did not present any statistically significant difference in terms of removal of organic material evaluated through ATP pres- 
ence. However, additional studies that will take into account other inputs and surfaces, as well as associating other cleaning/disinfection indicators are necessary to better clarify this issue and for the practice of evidence-based health care.

\section{REFERENCES}

1. Otter JA, Yezli S, Salkeld JA, French GL. Evidence that contaminated surfaces contribute to the transmission of hospital pathogens and an overview of strategies to address contaminated surfaces in hospital settings. Am J Infect Control. 2013; 41(Supp15):6-11.

2. Hota B, Blom DW, Lyle EA, Weinstein RA, Hayden MK. Interventional evaluation of environmental contamination by vancomycin-resistant enterococci: failure of personal, product, or procedure? J Hosp Infect. 2009; 71(2):123-31.

3. Rutala WA, Weber DJ, Healthcare Infection Control Practices Advisory Committee. Guideline for disinfection and sterilization in healthcare facilities [online]. 2008. [access 2015 May 21]. Available at: www.cdc.gov/hicpac/pdf/guidelines / Disinfection_Nov_2008.pdf

4. Siegel JD, Rhinehart E, Jackson M, Chiarello L. Health Care Infection Control Practices Advisory Committee. 2007 Guideline for isolation precautions: preventing transmission of infectious agents in health care settings. Am J Infect Control 2007; 35(Suppl 2):65-164.

5. Al-Hamad A, Maxwell S. How clean is clean? Proposed methods for hospital cleaning assessment. J Hosp Infect. 2008 Dec; 70(4):328-34.

6. Rutala WA, Weber DJ. Sterilization, high-level disinfection, and environmental cleaning. Infect Dis Clin North Am. 2011; 25(1):45-76.

7. Rutala WA, Weber DJ. Are room decontamination units needed to prevent transmission of environmental pathogens? Infect Control Hosp Epidemiol. 2011 Aug; 32(8):743-7.

8. Ferreira AM, Andrade D de, Rigotti MA, Ferreira MVF. Condition of cleanliness of surfaces close to patients in an intensive care unit. Rev Latino-Am Enfermagem. 2011 Jun; 19(3):557-64.

9. Otter JA, Yezli S, French GL. The role played by contaminated surfaces in the transmission of nosocomial pathogens. Infect Control Hosp Epidemiol. 2011; 32(7):687-99.

10. Dancer SJ: How do we assess hospital cleaning? A proposal for microbiological standards for surface hygiene in hospitals. J Hosp Infect. 2004 Jan; 56(1):10-5.

11. Sherlock O, O'Connell N, Creamer E, Humphreys $\mathrm{H}$. Is it really clean? An evaluation of the efficacy of four methods for determining hospital cleanliness. J Hosp Infect. 2009 Jun; 72(2):140-6.
12. Boyce JM, Havill NL, Havill HL, Mangione E, Dumigan DG, Moore BA. Comparison of fluorescent marker systems with 2 quantitative methods of assessing terminal cleaning practices. Infect Control Hosp Epidemiol. 2011; 32(12):1187-93.

13. Griffith CJ, Obee P, Cooper RA, Burton NF, Lewis M. The effectiveness of existing and modified cleaning regimens in a Welsh hospital. J Hosp Infect. 2007; 66(4):3529-9.

14. Carling P, Parry M, Bruno-Martha L, Dick B. Improving environmental hygiene in 27 intensive care units to decrease multidrug-resistant bacterial transmission. Crit Care Med. 2010 Apr; 38(4):1054-9.

15. Williams GJ, Denyer SP, Hosein IK, Hill DW, Maillard JY. Limitations of the efficacy of surface disinfection in the healthcare setting. Infect Control Hosp Epidemiol. 2009; 30(6):570-3.

16. Bergen LK, Meyer M, Hog M, Rubenhagen B, Andersen LP. Spread of bacteria on surfaces when cleaning with microfiber cloths. J Hosp Infect. 2009 Feb; 71(2):132-7.

17. Agência Nacional de Vigilância Sanitária (BR). Segurança do paciente em serviços de saúde: limpeza e desinfecção de superfícies. Agência Nacional de Vigilância Sanitária. Brasília (DF): ANVISA; 2012.

18. Collins BJ. The hospital environment: how clean should a hospital be? J Hosp Infect. 1988; 11 (Suppl A):53-56.

19. Malik RE, Cooper RA, Griffith CJ. Use of audit tools to evaluate the efficacy of cleaning systems in hospitals. Am J Infect Control. 2003 May; 31(3):181-7.

20. Graziano MU, Graziano KU, Pinto FMG, Bruna CQM, Queiroz RQ. Lascala CA. Effectiveness of disinfection with alcohol $70 \%(\mathrm{w} / \mathrm{v})$ of contaminated surfaces not previously cleaned. Rev Latino-Am Enfermagem. 2013; 21(2):618-23.

21. Lewis T, Griffith C, Gallo M, Weinbren M. A modified ATP benchmark for evaluating the cleaning of some hospital environmental surfaces. J Hosp Infect. 2008; 69(2):156-63.

22. Turner DE, Daugherity EK, Altier C, Maurer KJ. Efficacy and limitations of an ATP-based monitoring system. J Am Assoc Lab Anim Sci. 2010 Mar; 49(2):190-5.

23. Aiken ZA, Wilson N, Pratten J. Evaluation of ATP bioluminescence assays for potential use in a hospital setting. Infect Control Hosp Epidemiol. 2011 May; 32(5):507-9

24. Weber D, Rutala W, Miller M, Huslage K, Sickbert-Bennett E. Role of hospital surfaces in the transmission of emerging health care-associated pathogens: norovirus, Clostridium difficile and Acinetobacter species. Am J Infect Control. 2010 Jun; 38(5 Suppl 1):S25-33.

25. Attaway HH 3rd, Fairey S, Steed LL, Salgado CD, Michels HT, Schmidt MG. Intrinsic bacterial burden 
associated with intensive care unit hospital beds: effects of disinfection on population recovery and mitigation of potential infection risk. Am J Infect Control. 2012 Dec; 40(10):907-12.

26. Silva NO, Ferraz PC, Silva ALT, Malvezzi CK, Poveda VB. Avaliação da técnica de desinfecção dos colchões de uma unidade de atendimento a saúde. Rev Min Enferm [online]. 2011 [access 2014 Jun 02]; 15(2):242-7. Available at: http:/ / www.enf.ufmg. $\mathrm{br} /$ site_novo/modules/mastop_publish/files / files_4e662b005a6b3.pdf
27. Cordeiro AL, Oliveira MM, Fernandes JD, Barros CS, Castro LM. Contaminação de equipamentos em unidade de terapia intensiva. Acta Paul Enferm. 2015; 28(2):160-5.

28. Oliveira AC, Silva MDM, Garbaccio JL. Vestuário de profissionais de saúde como potenciais reservatórios de microrganismos: uma revisão integrativa. Texto Contexto Enferm [online]. 2012 Jul-Set [access 2014 Jun 02]; 21(3):684-91. Available at: http:/ /www. scielo.br/pdf/tce/v21n3/v21n3a25 